\title{
Large Carnivore Distribution in Relationship to Environmental and Anthropogenic Factors in a Multiple-use Landscape of Northern Tanzania
}

Felix J. Mkonyi ${ }^{1,2}$, Anna B. Estes ${ }^{1,3}$, Laly L. Lichtenfeld ${ }^{4} \&$ Sarah M. Durant ${ }^{5}$

${ }^{1}$ School of Life Sciences and Bioengineering, The Nelson Mandela African Institution of Science and Technology, P. O. Box 447, Arusha, Tanzania

${ }^{2}$ Department of Biological Sciences, Dar es Salaam University College of Education, P. O. Box 2329, Dar es Salaam, Tanzania

${ }^{3}$ The Huck Institutes of the Life Sciences, Pennsylvania State University, University Park, PA 16802 USA

${ }^{4}$ Tanzania People \& Wildlife Fund, Box 11306, Arusha, Tanzania

${ }^{5}$ Institute of Zoology, Zoological Society of London, UK Regent's Park, London, NW1 4RY;

United Kingdom (UK)

${ }^{1}$ Corresponding author: Tel: + 255 (0) 763741620 , e-mail: mkonyif@ nm-aist.ac.tz

Word count: 5216 words (Abstract: 200 / main text: 5016 excl. references, tables and figures)

Running title: Distribution and habitat use of large carnivores

\section{Acknowledgments}

We are grateful to the Tanzania Commission for Science and Technology (COSTECH), Tanzania National Parks authority (TANAPA) and Simanjiro District Council Authority for permission to conduct our research. We thank G. Kaunda, H. Saibogo and I. Lameck for their assistance in the field, and H. Shija for GIS support. This research was supported by the St. Louis Zoo's Wildcare Institute, Wildlife Conservation Society and Zoological Society of London.

\section{Conflict of Interest}

The authors declare no conflict of interest. 


\begin{abstract}
Effective management of threatened wildlife, particularly large carnivores, depends on a sound understanding of their spatial distribution and status in relationship to environmental or anthropogenic impacts. Here we analyse data from spoor surveys to investigate occurrence across a multiple-use landscape in the Tarangire-Simanjiro ecosystem in northern Tanzania for four taxa of African large carnivores: lions (Panthera leo), hyaenas (spotted hyaenas (Crocuta crocuta) and striped hyaenas (Hyaena hyaena) combined), cheetahs (Acinonyx jubatus) and leopards (P. pardus). We analysed our data using occupancy modeling, explicitly accounting for detectability, to identify associations with environmental and anthropogenic variables. Overall occurrence was estimated at $0.85(\mathrm{SE}=0.06)$ for hyaena, $0.82(\mathrm{SE}=0.15)$ for cheetah, $0.55(\mathrm{SE}$ $=0.10)$ for lion and $0.61(\mathrm{SE}=0.21)$ for leopard. Lion occurrence was negatively associated with distance to park boundary. Hyaena occurrence was positively associated with human population density and negatively associated with bushland, while cheetah and leopard occurrences were positively associated with grassland. These results suggest that lions may be more vulnerable to human impacts than other species, while hyaenas may benefit from vicinity to humans. Our study demonstrates the value of spoor-based occupancy surveys for understanding distribution and habitat-use of secretive large carnivores.
\end{abstract}

Keywords African large carnivores, human-wildlife coexistence, multiple-use landscape, occupancy modeling, spatial distribution, spoor surveys 


\section{Introduction}

Reliable information regarding species distribution patterns and the factors that influence their occurrence is critical to their effective management and conservation. However, obtaining quantitative information on the distribution and status of rare, elusive and often, nocturnal species, such as large carnivores, can be particularly challenging (Durant, Bashir, Maddox, \& Laurenson, 2007; Macdonald \& Loveridge, 2010). Because most of the world's large carnivore populations are in rapid decline (Ripple et al., 2014), there is an increasingly urgent need for efficient, practical and cost-effective methods that could be used to determine their population status and distribution across large areas (Funston et al., 2010; Mackenzie et al., 2006). Habitat loss and fragmentation, depletion of prey populations, hunting and illegal trade and persecution by humans, the latter primarily provoked by predation on livestock, are the main drivers of carnivore declines (Inskip \& Zimmermann, 2009). Large carnivores are particularly vulnerable to the effects of anthropogenic pressures because they come into conflict with humans; often range over large areas; and occur at relatively low population densities (Woodroffe, 2000).

Indirect sampling methods which rely on spoor counts along transects are often used by wildlife managers to estimate population densities and relative abundances of carnivore species such as cheetah (Acinonyx jubatus) (Houser, Somers, \& Boast, 2009), spotted hyaena (Crocuta crocuta), leopard (Panthera pardus), lions (P. leo) and African wild dogs (Lycaon pictus) (Funston et al., 2010; Stander, 1998). Spoor surveys are an effective non-invasive, inexpensive, repeatable and efficient method for detecting cryptic carnivores (Stander, 1998). Recent advances in occupancy modeling approach have provided a powerful statistical framework that allows analysis across a landscape, and enables the quantification of environmental and anthropogenic correlates of 
distribution, while accounting for detection error (Hines et al., 2010; Thorn, Green, Bateman, Waite, \& Scott, 2011). This takes the approach way beyond simple spoor density/abundance correlations. For large carnivores, occupancy modeling approaches are widely used to analyse camera trap data such as in Tanzania's Tarangire ecosystem (Msuha, 2009), in Ghana's Mole National Park (Burton et al., 2011), and in Kenya's Rift Valley (Schuette, Wagner, Wagner, \& Creel, 2013). Spoor surveys are more easily implemented across much larger areas than camera traps, and are thus particularly useful in generating data on spatial distribution over a relatively large landscape. Thus, there has been a growing interest in the use of spoor in an occupancy survey framework for surveying large carnivores, with recent studies investigating lions in Zambia's Kafue National Park (Midlane, 2013) and the W-Arly-Pendjari ecosystem, in the border region of Benin, Burkina Faso, and Niger (Henschel, Petracca, Hunter, \& Kiki, 2016), cheetah in Limpopo National Park in Mozambique (Andresen, Everatt, \& Somers, 2014), and leopard in Asia (Steinmetz, Seuaturien, \& Chutipong, 2013).

Scientists have identified a bias in information on large carnivores from within protected areas and a need for surveys outside protected areas due to increasing levels of anthropogenic pressure on large carnivore communities there (Durant et al., 2017; Msuha, 2009). In the Tarangire landscape in northern Tanzania, the focus of this study, information on large carnivores is limited to data from non-invasive camera trapping across relatively small areas, and where surveys on unprotected lands were hampered by camera theft (Msuha, 2009). Here we use spoor-based surveys as our detection method in order to estimate the occurrence and detection probabilities of four focal large carnivore taxa (lions, leopards, hyaenas and cheetahs) on unprotected and protected land across a multiple-use landscape in the Tarangire-Simanjiro ecosystem. The 
Tarangire ecosystem is an important stronghold for threatened large carnivore populations such as lions, cheetahs, leopards, hyaenas and African wild dogs, even though the National Park itself, encompassing 2,600 $\mathrm{km}^{2}$, is relatively small (TAWIRI, 2009). Because large carnivores range widely, securing their survival beyond, as well as within protected area boundaries is needed to maintain populations that are demographically and genetically viable (Msuha et al., 2012; Woodroffe \& Ginsberg, 1998). Thus, understanding the impacts of anthropogenic pressures, including changes in land use outside protected areas on large carnivores, both inside and outside protected areas, is key to securing their long-term viability (Carbone \& Gittleman, 2002).

Our specific objectives were to 1$)$ estimate the probability of occurrence $(\psi)$ and detection $(p)$ of focal large carnivore species across the study area; 2) evaluate environmental correlates of the distribution of the focal large carnivores; 3) evaluate how distributions of focal large carnivores are modified by key anthropogenic variables.

\section{Materials and Methods}

\section{Study Area}

This study was conducted in the Simanjiro Plains and Tarangire National Park (TNP) across the Tarangire-Simanjiro ecosystem (TSE) of northern Tanzania and lies between $3^{\circ} 52^{\prime}$ to $4^{\circ} 24^{\prime} \mathrm{S}$ and $36^{\circ} 05^{\prime}$ to $36^{\circ} 39^{\prime} \mathrm{E}$ (Figure 1). This region is characterized by bimodal rainfall averaging $650 \mathrm{~mm}$ per annum, with short rains (November-December) and long rains (March-May). The TSE is a mosaic of habitats comprised primarily of grassland (Digitaria macroblephara and Panicum coloratum), woodland (Acacia tortillis and Commiphora schimperi), bushland (Acacia stuhlmannii and A. drepanolobium) and seasonally water-logged bushed grassland (Pennisetum mezianum and Acacia stuhlmannii) (Kahurananga, 1979). 
We used the Land-use/Land-cover (LULC) maps of Tarangire-Manyara ecosystem for 2015. These were extracted from Landsat-8 Operational Land Imager (OLI) satellite images captured during the dry season in 2015 and obtained from the Unites States Geological Survey website (http://earthexplorer.usgs.gov/), with 30-m spatial resolution. We used the supervised objectoriented image classification technique (Green \& Congalton, 2012) to reclassify LULC types into eight broad classes: woodland, wetland, grassland, bushland, forest, agricultural land, bareland and other lands (Figure 1).

We divided the study area into three sample blocks based on an assessment of primary type of land use i.e. TNP/protected area $\left(337 \mathrm{~km}^{2}\right)$, communal grazing land $\left(414 \mathrm{~km}^{2}\right)$ and village land $\left(468 \mathrm{~km}^{2}\right)$ (Figure 1). The Tarangire National Park is the core protected area where no human settlement or hunting is allowed, and land uses are primarily restricted to wildlife-based tourism. The village land incorporates a wide variety of land uses including permanent human settlement, livestock grazing and cultivation. The communal grazing land does not include cultivation and is generally an open semiarid savanna with short grass plains and wooded grassland, encompassing the Simanjiro Game Controlled Areas which are administered by the Wildlife Division for licensed wildlife hunting and livestock grazing (Kahurananga \& Silkiluwasha, 1997). The Simanjiro plains are the main dispersal areas for wildlife during the wet season (November May) and grazing for pastoralists during the dry season (June - October). During the rainy season, most migratory wildlife species such as wildebeest (Connochaetes taurinus), zebra (Equus burchellii), hartebeest (Alcelaphus buselaphus) and fringe-eared oryx (Oryx beisacallotis) disperse away from TNP to areas in the east (Simanjiro plains), or north (Lakes Manyara and Natron) in search of better grazing and calving grounds. When they move out of 
the park, they may be followed by large carnivore species such as lion, cheetah, African wild dogs, spotted and striped hyaenas (Hyaena hyaena). Migratory wildlife eventually returns to TNP during the dry season (Kahurananga \& Silkiluwasha, 1997).

\section{Sampling design and field methods}

Transects were conducted in defined sampling units (grid cells) delineated in each respective survey block (Figure 1). We used a grid-based sampling approach to define sampling units (grid cells) for the study species as $15 \times 15-\mathrm{km}$ for lion, $30 \times 30-\mathrm{km}$ for cheetah and $10 \times 10-\mathrm{km}$ for leopard and hyaena based on their home range sizes (Figure 1). We used 1-km trail/road segments within each grid cell as spatial replicates (Hines et al., 2010; Karanth et al., 2011) to estimate detection probabilities and occurrence estimates. We assessed large carnivore occurrence at the site (= grid cell) level, and not at the level of each trail or road segment within grid cells. For adjacent segments of track, each new segment started exactly where the previous segment ends. We considered that the grid cells should be larger than the home range size of focal species to minimize the risk of spatial autocorrelation between neighbouring grid cells, but conservative enough to assume that if carnivore species were detected within a grid cell, the entire unit could be assumed to be used or occupied (Karanth et al., 2011; Mackenzie et al., 2006). The 15 x 15-km (225 $\left.\mathrm{km}^{2}\right)$ unit size was chosen for lion based on an estimated annual home range of approximately $209 \mathrm{~km}^{2}$ in the study area (Laizer, Tarimo, \& Kissui, 2014). Studies from other regions have estimated home range for cheetah to be $800 \mathrm{~km}^{2}$ for nonterritorial males and females in the Serengeti National Park (SNP) (Caro, 1994; Laver, 2005); for striped hyaenas $44 \mathrm{~km}^{2}$ for males and $72 \mathrm{~km}^{2}$ for females in the SNP (Kruuk, 1976); for spotted hyaenas $24.5 \mathrm{~km}^{2}$ (ranging from 9-40 $\mathrm{km}^{2}$ ) in Ngorongoro crater (Höner, Wachter, East, Runyoro, \& Hofer, 2005; Kruuk, 1976); and for male leopards $57.5 \mathrm{~km}^{2}$ and for females $50 \mathrm{~km}^{2}$ 
in the SNP (Schaller, 1972; Sunquist, 1983). Because our grid cells may have been smaller than the likely home range sizes of the focal large carnivore species we used occupancy as a measure of their habitat use instead of "true occupancy" (MacKenzie et al., 2002). We overlaid our grid cells on the land-cover matrix of the study area (Figure 1) using ArcGIS v10.3 (ESRI, Redlands, California).

\section{Spoor surveys}

We established spoor transects along the pre-existing road network and heavily-used cattle trails. We assessed the suitability of roads and trails in terms of substrate quality, accessibility and good network. We conducted spoor counts across two sampling occasions from August to November 2014 (dry season) and April to May 2015 (wet season) with the help of the experienced Hadza trackers. Hadzabe live in traditional hunter-gatherer communities and are well known for the reliability and high accuracy of their tracking skills (Lichtenfeld, 2005). We systematically drove transects on a four-wheel-drive vehicle traveling at a slow speed of 10 to $15 \mathrm{~km} / \mathrm{hour}$ (Funston et al., 2010) to maximize the likelihood of spoor detection and to minimize the likelihood of 'false absences' (Mackenzie et al., 2006). We identified 41 transects between 2 and $28 \mathrm{~km}$ in length, providing a total distance of $433 \mathrm{~km}$. These transects were then split into 1-km segments across grid cells for lion, cheetah, leopard and hyaena over the landscape. The number of 1-km replicate segments surveyed per grid cell varied according to transect coverage, ranging from 2 to 38 (100 $\left.\mathrm{km}^{2}\right), 2$ to $75\left(225 \mathrm{~km}^{2}\right)$ and 3 to $115\left(900 \mathrm{~km}^{2}\right)$. We used occupancy models to correct occurrence data for imperfections in the detection process and unequal sampling across sites (MacKenzie et al., 2002).

Two experienced observers sat on the bonnet/bumper and scanned for tracks directly ahead of the vehicle. When a fresh spoor ( $<24$ hours old) was encountered, the vehicle stopped and the 
spoor was assessed for species, group size, sex, age class, the GPS location, transect number, date, time, number of individuals and vegetation type. When new spoor were detected, the spoor were followed on foot to establish whether the spoor belonged to a new individual or whether it belonged to a previously recorded individual that had rejoined the track. We drove each transect repeatedly in a random order in six replicates (i.e. 3 times wet season, 3 times dry season), with at least 48 hours between temporal replicates to minimize double counting. During the dry season, roads and trails outside protected area were prepared 12 hours before sampling by dragging thorn bushes behind the observation vehicle. This could have introduced bias in our survey approach during the dry season, even though for nocturnal species this difference should not have a big impact since they will not be moving around during the day, thus 12 hours versus 24 hours should be equivalent.

We postponed sampling on roads/trails disturbed by rain in the previous 24 hours and ended if rain occurred at any stage during sampling. Spoor surveys were conducted in the early morning hours (generally between 05:30 and 11:00 hours) to take advantage of the low angle of the sun making it easier to detect spoor, and prior to the disturbance of the track by livestock and people. Spoor were recorded as individual spoor, not as a group of animals. We merged the detection histories for striped and spotted hyaenas because it was extremely difficult to differentiate their tracks using our survey protocol.

Data analysis 
We used single-season, single-species occupancy models in the program PRESENCE v. 11.5 (Hines, 2006) to estimate the probability of occurrence and detection for each species. We analysed our data according to separate surveys, and thus, we assume that sites were closed to changes in occupancy during each survey. Although the Hadzabe are experienced and reliable trackers, spoor identification was also always checked by the lead author. Due to the wideranging behavior of focal carnivore species, the assumption that detecting a species at one site is independent of detecting at all other sites (MacKenzie et al., 2002) may have been violated. Thus, data could not be used to estimate overall abundance, but focused on the Proportion of Area Used (PAU) by each species and the probability of occurrence. Occupancy models also assume that both detection and occupancy probabilities remain constant across survey sites (MacKenzie et al., 2002). Spatial variation in abundance may induce heterogeneity in both parameters in our study area, hence we overcame this violation by including relevant covariates in the occupancy analysis (Royle \& Nichols, 2003). We analysed each focal carnivore species separately, since differences in ecology and behavior were expected to affect habitat use and detection probability.

\section{Model covariates}

The PAU by the focal carnivore species and the probability of detecting them $(p)$ are functions of environmental and anthropogenic covariates. We extracted environmental and anthropogenic covariates likely to influence carnivore occurrence and detection probabilities from GIS layers using ArcGIS v10.3 (ESRI, Redlands, California). We identified fourteen predictor variables (covariates) expected to influence large carnivore occurrence in the study area: environmental variables [i.e., elevation, slope, distance to permanent water, proportions of woodland, grassland, bushland, forest, wetland, agricultural land, bareland and other lands], anthropogenic variables 
[i.e., distance to nearest village, distance to park boundary and human population density as proxy for human influence] (Online Appendix A, Table A1). We calculated distance to villages and park boundary by taking the distance from the center of each grid cell to the nearest village or park boundary. Distance to park boundary was calculated as an absolute value that is always analyzed as an interaction term with the variable returning whether a site is inside or outside the park. We also expected carnivore detectability $(p)$ to vary with season (dry, August - November, versus wet, April-May) and proportion of habitat available within each grid cell (woodland, grassland, bushland, forest, wetland, agricultural land, bareland and other lands), so we included both as covariates in detection models.

We assumed that large carnivore occurrence would be influenced by environmental and anthropogenic variables affecting species presence, while detection of large carnivores would be influenced primarily by variables affecting spoor detectability on roads, primarily habitat (which may influence road use) and season (which affects spoor visibility). We also assumed that each focal large carnivore species used roads or trails with an equal frequency across sampling blocks and seasons.

We selected covariates for occupancy modeling based on a priori knowledge of habitat preferences of the focal carnivore species. We first ran all models without additional covariates to allow comparisons of occupancy and probability of detection across species, survey blocks and seasons using the null model $\psi(),. p($.$) , where occupancy and detection probability are held$ constant. Then, we constructed models for each species to examine the effect of habitat and season covariates on detection probability $p$ through univariate and multivariate analyses while 
holding $\psi$ constant i.e. $\psi()$.$p (covariate) (Karanth et al., 2011). Finally, we modeled the effect of$ site covariates on occupancy probability $\psi$ while holding $p$ constant i.e. $\psi($ covariate) $p($.$) (Karanth$ et al., 2011). We constructed models where both occupancy and probability of detection were allowed to vary with individual or additive combination of the covariates. We scaled and/or standardized all continuous covariates to $z$-scores prior to analysis to optimize model convergence (Cooch \& White, 2005). We used a Spearman's correlation matrix in program SPSS v.22.0 (SPSS Inc., Chicago, Illinois, USA) to test for multi-collinearity between continuous covariates using a cut-off of $(\mathrm{r} \geq|0.80|)$ (see Tables S1-S3, Supporting information). Where it happens that two covariates were highly correlated (i.e., $r \geq 0.80$ ), we dropped one of the highly correlated covariates from the analysis (i.e., the one with lower AICc score).

\section{Model selection and assessment of model fit}

We selected the best-performing models based on the Akaike Information Criterion (AIC) corrected for small sample sizes (AICc) and model weights ( $\omega$ i) (Burnham \& Anderson, 2002; Mackenzie et al., 2006). We considered models with highest AIC weights ( $\omega$ i) and the lowest AIC values $(\triangle \mathrm{AICc}<2)$ as having the best fit to the data and considered variables from these models important in predicting species occupancy and detectability (Burhan \& Anderson, 2002). The estimated $c$-hat value for site occupancy models was close to 1 and did not suggest overdispersion or lack of fit (Burhan \& Anderson, 2002). We used model-averaging for competing models (i.e., models within $2 \Delta \mathrm{AICc}$ to estimate $\psi, p$, and covariate coefficients) (Burhan \& Anderson, 2002). We also calculated variable importance weights, which are the sum of the model weights of all models that contain a given variable.

\section{Results}


We detected a total of 932 spoor incidents, 56 for cheetahs, 136 for lions, 24 for leopards and 716 for hyaenas over 41 transects representing 433 1-km replicates across 34 surveyed cells for hyaena and leopard, 20 cells for lion and 10 cells for cheetah. We did not detect African wild dogs.

\section{Detection probability}

The probability of carnivore detection varied greatly between species and seasons. For cheetah and leopard, the probability of detection was highest during the dry season $(p+/-\mathrm{SE}=0.45+/-$ $0.13)$ and $(p+/-\mathrm{SE}=0.18+/-0.11)$ respectively, than in the wet season $(p+/-\mathrm{SE}=0.38+/$ $0.19)$ and $(p+/-\mathrm{SE}=0.02+/-0.01)$ respectively. However, hyaena had a higher probability of detection in the wet season $(p+/-\mathrm{SE}=0.73+/-0.06)$ than in the dry season $(p+/-\mathrm{SE}=0.60+/-$ 0.06). For lion, the probability of detection was not significantly different between wet $(p+/-\mathrm{SE}$ $=0.50+/-0.09)$ and dry seasons $(p+/-\mathrm{SE}=0.50+/-0.14)$. Hyaena had the highest overall probability of detection $(p+/-\mathrm{SE}=0.64+/-0.04)$, while leopard had the lowest overall detection $(p+/-\mathrm{SE}=0.10+/-0.05)$.

\section{Occurrence probability}

Overall occurrence $(\psi)$ estimates from models with no covariates varied significantly between species. Hyaena showed highest overall occurrence $\psi=0.85(\mathrm{SE}=0.06)$, using $85 \%$ or approximately $3400 \mathrm{~km}^{2}$ of potential habitat, followed closely by cheetah $\psi=0.84(\mathrm{SE}=0.14)$ and leopard $\psi=0.70(\mathrm{SE}=0.33)$, while lion had the lowest overall occurrence $\psi=0.56(\mathrm{SE}=$ $0.11)$.

\section{Hyaena}


During the dry season, hyaena had the highest probability of occurrence on village land, followed closely by the park and then communal grazing land in that order $(t=20.89, d f=2, p=$ $0.002)$, but the reverse was true in the wet season $(t=8.34, d f=2, p=0.014$, Figure 2$)$. The best fit model for detection was the null model $\Psi(),. p($.$) , indicating that covariates had no effect on$ detection probability (Table 1). Hyaena occurrence was strongly positively associated with human population density $\left(\beta=2.03, \mathrm{SE}=0.81 ; \sum \mathrm{w}=0.65\right)$, and strongly negatively associated with the proportion of bushland cover $\left(\beta=-11.10, \mathrm{SE}=4.96 ; \sum \mathrm{w}=0.68\right)$ (Table 3). The

averaged models for overall estimated occurrence and detection probabilities were $\widehat{\bar{\Psi}}=0.85$ (SE $=0.06)$ and $\hat{\bar{p}}=0.63(\mathrm{SE}=0.04)$ respectively.

\section{Cheetah}

Cheetah had the highest probability of occurrence in the village and communal grazing lands during the dry season $(t=22.07, d f=2, p=0.002)$, while in the wet season there was no significant difference in occurrence between different land use types $(p>0.05$, Figure 2$)$. Grassland $(\beta=17.75, \mathrm{SE}=11.18)$ was an important positive predictor of cheetah occurrence (Table 3). Cheetah detection was higher in the dry season than in the wet season $(\beta=-1.17, \mathrm{SE}=$ 0.48). The averaged models for overall estimated occurrence and detection probabilities were $\widehat{\bar{\Psi}}$ $=0.82(\mathrm{SE}=0.15)$ and $\hat{\bar{p}}=0.38(\mathrm{SE}=0.07)$ respectively (Table 1$)$.

\section{Lion}

The probability of occurrence $(\psi)$ estimate from the model with no covariates showed that lion had the highest occurrence estimates on village land, followed closely by the park during the dry season (Figure 2). We failed to detect lions on communal grazing land over the entire sampling period (Figure 3). After adjusting for imperfect detection, lion occurrence across the entire 
landscape was lower near water sources $(\beta=1.35, \mathrm{SE}=0.97)$ and greater closer to or within protected area $(\beta=-3.16, \mathrm{SE}=1.66$; Table 3$)$. The model-averaged estimate of lion detectability was $<1(\hat{\bar{p}}=0.49, \mathrm{SE}=0.06)$ and the overall estimate of occurrence was $\widehat{\bar{\Psi}}=0.55(\mathrm{SE}=0.10)$ (Table 2). However, within the National Park, lion occurrence was negatively associated with (1) distance to permanent water $(\beta=-0.84, \mathrm{SE}=1.42)$ and (2) distance to village (Online Appendix A, Table A2). In the village land, lion occurrence was positively associated with distance to permanent water, and negatively associated with distance to park boundary.

\section{Leopard}

Leopard had the highest occurrence on the village and communal grazing lands than in the park during the dry season when all covariates were excluded $(t=7.82, d f=2, p=0.016$, Figure 2). There was no difference in the occurrence estimates between village land, communal grazing land and the park during the wet season $(t=2.00, d f=2, p=0.183)$. Rather surprisingly, leopard occurrence was associated with a higher proportion of grassland $(\beta=3.40, \mathrm{SE}=3.50)$ (Table 3). The model-averaged estimate of leopard detectability was $<1(\hat{p}=0.11, \mathrm{SE}=0.04)$ and the overall estimate of occurrence was $\widehat{\Psi}=0.61(\mathrm{SE}=0.21)($ Table 2$)$.

Human population density had the strongest anthropogenic influence on occurrences across species $\left(\sum \mathrm{w}=1.00\right)$, followed by distance to park boundary $\left(\sum \mathrm{w}=0.69\right)$ and distance to village $\left(\sum \mathrm{w}=0.13\right)$. On the other hand, grassland cover had the strongest environmental influence on occurrences across species $\left(\sum \mathrm{w}=1.03\right)$, followed by bushland cover $\left(\sum \mathrm{w}=0.95\right)$, distance to permanent water $\left(\sum \mathrm{w}=0.50\right)$, woodland cover $\left(\sum \mathrm{w}=0.33\right)$, agricultural land cover $\left(\sum \mathrm{w}=0.29\right)$, slope $\left(\sum \mathrm{w}=0.14\right)$ and bareland cover $\left(\sum \mathrm{w}=0.11\right)$. 


\section{Discussion}

This study provides a detailed analysis of large carnivore occurrence from spoor count data across a multiple-use landscape in northern Tanzania. We were able to explore the distribution of a diverse large carnivore guild across a broader landscape compared with previous studies (Lichtenfeld, 2005; Msuha, 2009). The overall results uphold our predictions that anthropogenic and environmental variables influence the probability of occurrence of large carnivores in the Tarangire landscape. The influence of these variables on habitat use and occurrence were species-specific, likely due to the differences in ecology and behavior of the focal large carnivores. Lion and hyaena occurrences showed the strongest relationship with anthropogenic factors. As previous studies have shown (Online Appendix A, Table A1), the probability of lion occurrence outside the park declined with increasing distance from the park boundary, suggesting that lions may be more vulnerable to human impacts than other species. This finding corroborates the importance of full protection within the National Park for lions, and is consistent with a previous study showing that lion density is higher in the TNP as compared to areas outside its boundaries (Lichtenfeld, 2005). We also found that lions avoided agricultural landscapes, providing evidence that habitat conversion to agriculture could have serious implications for lion distribution due to their particular sensitivity to anthropogenic influences (Loveridge, Hemson, Davidson, \& Macdonald, 2010; Valeix, Hemson, Loveridge, Mills, \& Macdonald, 2012). In the National Park, where areas surrounding water bodies are protected, lions were strongly associated with permanent water. This is consistent with patterns observed by Hayward \& Kerley, (2005, 2008), who found that close proximity to water increases the likelihood of use by lions, where encounter rates with water-dependent herbivores may be higher. In contrast, in the village land, lions strongly selected sites that were farther from 
permanent water, suggesting that lions were possibly avoiding encounters with people around water bodies, likely because water acts as a proxy for human activities (cf. Sunarto, Kelly, Parakkasi, Klenzendorf, \& Septayuda, 2012). We did not detect any lions in the communal grazing land, suggesting that there may be strong avoidance of these areas, perhaps due to persecution in form of poisoning and preventative or retaliatory killing (Kissui, 2008). However, this result should be interpreted cautiously, as the bias in our survey approach could have had reduced lion occurrence probability in this block.

Contrary to our predictions, higher hyaena occurrence was associated with greater human population density across the study area, suggesting that they may be finding benefits from vicinity to humans, such as scavenging thrown away food or carcasses (Kolowski \& Holekamp, 2007; Yirga et al., 2015). Hyaenas avoided bushland habitat and appeared to prefer open grassland habitats, where it might be easier to find scavenged food (Hayward, 2006). Of all carnivore species surveyed, hyaena had the highest overall estimated occurrence and detection probability across habitat types and seasons, possibly due to their adaptability, wide-ranging habits and resilient behavior (Van Meter et al., 2009). Overall results showed that occurrence and detection probability estimates for hyaenas were statistically robust and were highest on village land and communal grazing land than inside the park.

Contrary to our expectations, leopard occurrence was unrelated to proportions of forest and woodland cover, but was positively related to the proportion of grassland cover. However, this result should be interpreted cautiously, as leopards usually avoid grassland habitat (Durant et al., 2010). We suspect this may be an artifact of wet season concentration of migratory prey in these 
areas. Alternatively, the small sample size of leopard in this study $(n=24)$ could have led to potentially spurious results due to overfitting of complex models (Stockwell \& Peterson, 2002). On the other hand, leopards are unlikely to be found in open areas in the dry season which may have induced a substantial amount of bias in our results. In addition, we found that the leopard used village and communal grazing lands considerably more often and the park considerably less during both dry and wet seasons. Previous studies have shown that leopards exhibit remarkable behavioral plasticity in terms of habitat selection and they can do better in human-dominated landscapes (Nowell \& Jackson, 1996).

Consistent with our predictions, cheetah occurrence was positively associated with grassland in the study area. This result concurs with previous studies showing that cheetahs prefer open grasslands (Caro, 1994; Durant, Caro, Collins, Alawi, \& FitzGibbon, 1988), although they can also inhabit a wide range of bush, scrub and woodland habitats (Myers, 1975; Nowell \& Jackson, 1996; Purchase \& du Toit, 2000). Therefore, our results should be interpreted with caution, as like leopard, this association may be an artifact of wet season concentration of migratory prey in these areas or may be a spurious result due to the low number of cheetah detections in this study $(n=56)$.

\section{Conclusion and management implications}

This study demonstrates the efficacy of spoor-based occupancy models in establishing the distribution of a guild of large carnivores across a multiple-use landscape. However, more sampling effort would increase confidence in our results for cheetah and leopard. Our findings emphasize the importance of protected areas, water availability, grassland habitat availability and the remaining natural habitats outside of formal protected area network for large carnivore 
conservation in the region. Hence, in order to achieve conservation targets for large carnivores, wildlife managers should consider maintaining habitat connectivity between existing protected areas and areas outside of formal protected area networks. In addition, further studies would be useful to understand the mechanisms of human-wildlife interactions in relation to anthropogenic land modification in order to achieve coexistence with large carnivores. From a conservation perspective, it is vitally important to conserve protected areas and create buffers for wildlife, such as wildlife corridors in communal and village lands.

Our occupancy modeling approach allowed effective analysis of data sampled from a very large area with limited access and resources, but also explicitly addressed imperfect detection of large carnivore tracks. However, this approach was constrained by low detection probability (for cheetah and leopard), limited number of grid cells (for cheetah and lions), grid-cell size, transect length within each grid cell and limited road networks with suitable substrate for tracking which might affect the strength of inference. We strongly recommend increasing sample size and spatial replication of grid cells in future surveys, as this will increase the detection probabilities and improve precision of occurrence estimates (MacKenzie et al., 2002). We also encourage additional examination of environmental and anthropogenic covariates that could influence detection and occupancy of large carnivores in the study area. Future studies should seek to supplement spoor count data with call-up (for lions and hyaenas), camera-trapping and radiotracking surveys (for lions, hyaenas, African wild dogs, cheetah and leopards) in order to increase detection probabilities and the precision of the occurrence estimates. Our study has demonstrated that a spoor-based occupancy survey is a valuable approach for assessing the distribution and habitat-use patterns of wide-ranging carnivore species across a wider landscape. 


\section{References}

Andresen, L., Everatt, K. T., \& Somers, M. J. (2014). Use of site occupancy models for targeted monitoring of the cheetah. Journal of Zoology, 292, 212-220. https://doi.org/10.1111/jzo.12098

Burhan, K. P., \& Anderson, D. R. (2002). Model selection and multimodel inference. A Practical Information-Theoretic Approach (2nd ed.). New York: Springer.

Burnham, K. P., \& Anderson, D. R. (2002). Model Selection and Multimodel Inference. A Practical Information-Theoretic Approach. 2nd edn. Springer, New York.

Burton, A. C., Sam, M. K., Kpelle, D. G., Balangtaa, C., Buedi, E. B., \& Brashares, J. S. (2011). Evaluating persistence and its predictors in a West African carnivore community. Biological Conservation, 144, 2344-2353. https://doi.org/10.1016/j.biocon.2011.06.014

Carbone, C., \& Gittleman, J. L. (2002). A Common Rule for the Scaling of Carnivore Density. Science, 295, 2273-2276. https://doi.org/10.1126/science.1067994

Caro, T. M. (1994). Cheetahs of the Serengeti Plains: Group Living in an Asocial Species. University of Chicago Press.

Congalton, R., \& Green K. (2008). Assessing the accuracy of remotely sensed data: principles and practices. Second Edition CRC Press.

Cooch, E., \& White, G. C. (2005). Program MARK: a gentle introduction. Retrieved 10 January 2017, from http://www.phidot.org/software/mark/docs/book.

Durant, S. M., Bashir, S., Maddox, T., \& Laurenson, M. K. (2007). Relating long-term studies to conservation practice: the case of the Serengeti Cheetah Project. Conservation Biology: The Journal of the Society for Conservation Biology, 21, 602-611. https://doi.org/10.1111/j.1523-1739.2007.00702.x 
Durant, S. M., Caro, T. M., Collins, D. A., Alawi, R. M., \& FitzGibbon, C. D. (1988). Migration patterns of Thomson's gazelles and cheetahs on the Serengeti Plains. African Journal of Ecology, 26, 257-268. https://doi.org/10.1111/j.1365-2028.1988.tb00978.x

Durant, S. M., Craft, M. E., Foley, C., Hampson, K., Lobora, A. L., Msuha, M., ... Pettorelli, N. (2010). Does size matter? An investigation of habitat use across a carnivore assemblage in the Serengeti, Tanzania. Journal of Animal Ecology, 79, 1012-1022. https://doi.org/10.1111/j.1365-2656.2010.01717.x

Durant, S. M., Mitchell, N., Groom, R., Pettorelli, N., Ipavec, A., Jacobson, A. P., ... YoungOvertone, K. (2017). The global decline of cheetah Acinonyx jubatus and what it means for conservation. Proceedings of National Academy of Sciences. U. S. A, 114, 528-533. https://doi.org/10.1073/pnas.1611122114

Funston, P. J., Frank, L., Stephens, T., Davidson, Z., Loveridge, A., Macdonald, D. W., ... Ferreira, S. M. (2010). Substrate and species constraints on the use of track incidences to estimate African large carnivore abundance. Journal of Zoology, 281, 56-65. https://doi.org/10.1111/j.1469-7998.2009.00682.x

Hayward, M. W. (2006). Prey preferences of the spotted hyaena (Crocuta crocuta) and degree of dietary overlap with the lion (Panthera leo). Journal of Zoology, 270, 606-614. https://doi.org/10.1111/j.1469-7998.2006.00183.x

Hayward, M. W., \& Kerley, G. I. H. (2005). Prey preferences of the lion (Panthera leo). Journal of Zoology, 267, 309-322. https://doi.org/10.1017/S0952836905007508

Hayward, M. W., \& Kerley, G. I. H. (2008). Prey preferences and dietary overlap amongst Africa 's large predators. South African Journal of Wildlife Research, 38, 93-108. https://doi.org/10.3957/0379-4369-38.2.93 
Henschel, P., Petracca, L. S., Hunter, L. T. B., \& Kiki, M. (2016). Determinants of Distribution Patterns and Management Needs in a Critically Endangered Lion Panthera leo Population. Frontiers in Ecology and Evolution, 4, 110. https://doi.org/10.3389/fevo.2016.00110

Hines, J. (2006). PRESENCE 11.5 Software to measure patch occupancy and related parameters. USGS-PWRC. Retrieved 20 September 2016, from http://www.mbrpwrc.usgs.gov/software/presence.html.

Hines, J. E., Nichols, J. D., Royle, J. A., Mackenzie, D. I., Gopalaswamy, A. M., Kumar, N. S., \& Karanth, K. U. (2010). Tigers on trails: occupancy modeling for cluster sampling. Ecological Applications, 20, 1456-1466. https://doi.org/10.1890/09-0321.1

Höner, O. P., Wachter, B., East, M. L., Runyoro, V. A., \& Hofer, H. (2005). The effect of prey abundance and foraging tactics on the population dynamics of a social , territorial carnivore, the spotted hyaena. OIKOS, 108, 544-554. https://doi.org/10.1111/j.00301299.2005.13533.x

Hofer, H., \& East, M. L. (1993). The commuting system of Serengeti spotted hyaenas: how a predator copes with migratory prey. III. Attendance and maternal care. Animal Behaviour, 46(3), 575-589. https://doi.org/10.1006/anbe.1993.1224

Houser, A. M., Somers, M. J., \& Boast, L. K. (2009). Spoor density as a measure of true density of a known population of free-ranging wild cheetah in Botswana. Journal of Zoology, 278, 108-115. https://doi.org/10.1111/j.1469-7998.2009.00554.x

IUCN. (2016). IUCN Red List of threatened species: A Global Assessment.Gland, Switzerland. Retrieved 10 December 2016, from http://www.iucnredlist.org.

Kahurananga, J. (1979). The vegetation of the Simanjiro Plains, Northern Tanzania. African Journal of Ecology, 17, 65-83. https://doi.org/10.1111/j.1365-2028.1979.tb00459.x 
Kahurananga, J., \& Silkiluwasha, F. (1997). The migration of zebra and wildebeest between Tarangire National Park and Simanjiro Plains, northern Tanzania, in 1972 and recent trends. African Journal of Ecology, 35, 179-185. https://doi.org/10.1111/j.1365-2028.1997.07189071.X

Karanth, K. U., Gopalaswamy, A. M., Kumar, N. S., Vaidyanathan, S., Nichols, J. D., \& Mackenzie, D. I. (2011). Monitoring carnivore populations at the landscape scale: occupancy modelling of tigers from sign surveys. Journal of Applied Ecology, 48, 10481056. https://doi.org/10.1111/j.1365-2664.2011.02002.x

Kissui, B. M. (2008). Livestock predation by lions, leopards, spotted hyaenas, and their vulnerability to retaliatory killing in the Maasai steppe, Tanzania. Animal Conservation, 11, 1-11. https://doi.org/10.1111/j.1469-1795.2008.00199.x

Kolowski, J. M., \& Holekamp, K. E. (2007). Effects of an open refuse pit on space use patterns of spotted hyaenas. African Journal of Ecology, 46, 341-349. https://doi.org/10.1111/j.1365-2028.2007.00846.x

Kruuk, H. (1976). Feeding and social behaviour of the striped hyaena (Hyaena vulgaris Desmaret). East African Wildlife Journal, 14, 91-111. https://doi.org/10.1111/j.13652028.1976.tb00155.x

Laizer, H., Tarimo, T. M. C., \& Kissui, B. M. (2014). Home Range and Movement Patterns of Lions (Panthera leo) in Tarangire National Park, Tanzania. American Journal of Research Communication, 2, 44-58.

Laver, P. N. (2005). Cheetah of the Serengeti Plains: A home range analysis. Msc. Thesis. State University.

Lichtenfeld, L. L. (2005). Our Shared Kingdom At Risk: Human - Lion Relationships in the 21 
st Century. PhD Thesis,. Yale University.

Loveridge, A. J., Hemson, G., Davidson, Z., \& Macdonald, D. W. (2010). African lions on the edge: reserve boundaries as 'attractive sinks'. In: Macdonald DW, Loveridge A.J, editors. Biology and conservation of Wild Felids. New York: Oxford University Press. pp. 283-304.

Macdonald, D. W., \& Loveridge, A. J. (2010). Biology and conservation of wild felids. (A. J. Macdonald, D.W., \& Loveridge, Ed.). Oxford: Oxford University Press.

MacKenzie, D. I., Nichols, J. D., Lachman, G. B., Droege, S., Royle, A. J. A., \& Langtimm, C. A. (2002). Estimating site occupancy rates when detection probabilities are less than one. Ecology, $\quad 83, \quad 2248-2255 . \quad$ https://doi.org/10.1890/00129658(2002)083[2248:ESORWD]2.0.Co;2

Mackenzie, D. I., Nichols, J. D., Royle, J. A., Pollock, K., Bailey, L., \& Hines, J. E. (2006). Occupancy Estimation and Modelling - Inferring Patterns and Dynamics of Species Occurrence. London, UK: Elsevier Academic Press.

Midlane, N. (2013). The conservation status and dynamics of a protected African lion Panthera leo population in Kafue National Park, Zambia. PhD. Thesis. University of Cape Town.

Msuha, M. J. (2009). Human impacts on carnivore biodiversity inside and outside protected areas in Tanzania. PhD Thesis,. University College London (UCL).

Msuha, M. J., Carbone, C., Pettorelli, N., \& Durant, S. M. (2012). Conserving biodiversity in a changing world: land use change and species richness in northern Tanzania. Biodiversity and Conservation, 21, 2747-2759. https://doi.org/10.1007/s10531-012-0331-1

Myers, N. (1975). The cheetah Acinonyx jubatus in Africa. International Union of the Conservation of Nature, (Vol. 4).

Nowell, K., \& Jackson, P. (1996). Wild Cats: Status Survey and Conservation Action Plan. 


\section{IUCN/SSC Cat Specialist Group. IUCN.}

Purchase, G. K., \& du Toit, J. T. (2000). The use of space and prey by cheetahs in Matusadona National Park, Zimbabwe. South African Journal of Wildlife Research, 30, 139-144.

Ripple, W. J., Estes, J. A., Beschta, R. L., Wilmers, C. C., Ritchie, E. G., Hebblewhite, M., ... Wirsing, A. J. (2014). Status and ecological effects of the world's largest carnivores. Science, 343, 1241484-1-1241484-11. https://doi.org/10.1126/science.1241484

Royle, J. A., \& Nichols, J. D. (2003). Estimating Abundance from Repeated Presence-Absence Data or Point Counts. Ecology, 84, 777-790. https://doi.org/10.1890/00129658(2003)084[0777:EAFRPA]2.0.Co;2

Schaller, G. B. (1972). The Serengeti Lion: a Study of Predator-Prey Relations. Chicago. University of Chicago Press,.

Schuette, P., Wagner, A. P., Wagner, M. E., \& Creel, S. (2013). Occupancy patterns and niche partitioning within a diverse carnivore community exposed to anthropogenic pressures. Biological Conservation, 158, 301-312. https://doi.org/10.1016/j.biocon.2012.08.008

Stander, P. E. (1998). Spoor counts as indices of large carnivore populations: The relationship between spoor frequency, sampling effort and true density. Journal of Applied Ecology, 35, 378-385. https://doi.org/10.1046/j.1365-2664.1998.00313.x

Steinmetz, R., Seuaturien, N., \& Chutipong, W. (2013). Tigers, leopards, and dholes in a halfempty forest: Assessing species interactions in a guild of threatened carnivores. Biological Conservation, 163, 68-78. https://doi.org/10.1016/j.biocon.2012.12.016

Stockwell, D. R., \& Peterson, A. . (2002). Effects of sample size on accuracy of species distribution models. Ecological Modeling, 148, 1-13. https://doi.org/10.1016/S03043800(01)00388-x 
Sunarto, S., Kelly, M. J., Parakkasi, K., Klenzendorf, S., \& Septayuda, E. (2012). Tigers Need Cover: Multi-Scale Occupancy Study of the Big Cat in Sumatran Forest and Plantation Landscapes. PLoS ONE, 7, e30859. https://doi.org/10.1371/journal.pone.0030859

Sunquist, M. E. (1983). Dispersal of three radio-tagged leopards. Journal of Mammalogy, 64, 341-345. https://doi.org/10.2307/1380574

TAWIRI. (2009). Tanzania Carnivore Conservation Action Plan. TAWIRI. Arusha, Tanzania.

Thorn, M., Green, M., Bateman, P. W., Waite, S., \& Scott, D. M. (2011). Brown hyaenas on roads : Estimating carnivore occupancy and abundance using spatially auto-correlated sign survey replicates. Biological Conservation, 144, 1799-1807. https://doi.org/10.1016/j.biocon.2011.03.009

United States Geological Survey (2015). Earth Explorer. Retrieved 10 September 2015 from http://earthexplorer.usgs.gov/

Valeix, M., Hemson, G., Loveridge, A. J., Mills, M. G. L., \& Macdonald, D. W. (2012). Behavioural adjustments of a large carnivore to access secondary prey in a humandominated landscape. Journal of Applied Ecology, 49, 73-81. https://doi.org/10.1111/j.1365-2664.2011.02099.x

Valeix, M., Loveridge, A. J., Chamaille-James, S., Davidson, Z., Murindagomo, F., Fritz, H., \& Macdonald, D. W. (2009). Behavioral adjustments of African herbivores to predation risk by lions: Spatiotemporal variations influence habitat use. Ecology, 90, 23-30. https://doi.org/10.1890/08-0606.1

Valeix, M., Loveridge, A. J., Davidson, Z., Madzikanda, H., Fritz, H., \& Macdonald, D. W. (2010). How key habitat features influence large terrestrial carnivore movements: Waterholes and African lions in a semi-arid savanna of north-western Zimbabwe. 
Landscape Ecology, 25, 337-351. https://doi.org/10.1007/s10980-009-9425-x

Van Meter, P. E., French, J. A., Dloniak, S. M., Watts, H. E., Kolowski, J. M., \& Holekamp, K. E. (2009). Fecal glucocorticoids reflect socio-ecological and anthropogenic stressors in the lives of wild spotted hyaenas. Hormones and Behavior, 55, 329-337. https://doi.org/10.1016/j.yhbeh.2008.11.001

Woodroffe, R., \& Ginsberg, J. R. (1998). Edge Effects and the Extinction of Populations Inside Protected Areas. Science, 280, 2126-2128. https://doi.org/10.1126/science.280.5372.2126

Yirga, G., Iongh, H. H. De, Leirs, H., Gebrehiwot, K., Deckers, J., \& Bauer, H. (2015). Food base of the spotted hyaena (Crocuta crocuta) in Ethiopia. Wildlife Research, 42, 19-24. https://doi.org/10.1071/WR14126 